Bài báo khoa học

\title{
Phân tích cơ chế gây mưa lớn từ ngày 1/8/2019 đến 5/8/2019 tại Phú Quốc
}

\author{
Nguyễn Đăng Mậu ${ }^{*}$, Hoàng Thị Huyền ${ }^{1}$, Vũ Quốc Tuấn² \\ ${ }^{1}$ Viện Khoa học Khí tượng Thủy văn và Biến đổi khí hậu; mau.imhen@gmail.com; \\ huyenht.imh@gmail.com \\ ${ }^{2}$ Trung tâm Dự báo Khí tượng Thủy văn Quốc gia; vuquoctuan5895@gmail.com \\ *Tác giả liên hệ: mau.imhen@gmail.com; Tel.: +84-382072468
}

Ban Biên tập nhận bài: 10/3/2021; Ngày phản biện xong: 17/4/2021; Ngày đăng bài: $25 / 5 / 2021$

Tóm tắt: Trong nghiên cứu này, cơ chế gây mưa lớn tại Phú Quốc từ 1/8-5/8/2019 được phân tích dựa trên số liệu mưa quan trắc, số liệu mưa vệ tinh và số liệu FNL. Kết quả nghiên cứu cho thấy, mưa lớn tại Phú Quốc gắn liền với sự tăng cường mạnh mẽ của gió mùa mùa hè Châu Á, có mối liên hệ chặt chẽ với chỉ số VSMI. Sự tăng cường của gió mùa mùa hè này nằm trong pha hoạt động mạnh của BSISO với chu kì khoảng 30 ngày. Sự hoạt động của dao động nội mùa khiến cho áp thấp ở Ấn Độ và Tây Thái Bình Dương khơi sâu, tạo nên khu vực hội tụ gió mạnh tại Phú Quốc và gây ra mưa lớn cho khu vực này.

Từ khóa: Mưa lớn; Dao động nội mùa; Hoàn lưu quy mô lớn.

\section{Mở đầu}

Mưa lớn xuất hiện thường xuyên ở Việt Nam từ tháng Tư đến tháng Mười Một và gây ra những hậu quả nghiêm trọng như lũ quét và sạt lở đất [1-8], do đó, rất nhiều nghiên cứu đã được thực hiện nhằm tìm hiểu cơ chế gây mưa lớn ở Việt Nam. Mưa lớn ở Bắc Bộ thường được gây ra bởi sự kết hợp của nhiều hình thế thời tiết khác nhau như xoáy thuận nhiệt đới kết hợp với gió đồng nam, xoáy thuận nhiệt đới kết hợp với không khí lạnh, không khí lạnh kết hợp với hội tụ gió tín phong, rãnh thấp nóng phía tây kết hợp với không khí lạnh...[2-3]. Ở Trung Bộ, mưa lớn thường gây ra bởi bão, áp thấp nhiệt đới, dải hội tụ nhiệt đới kết hợp với không khí lạnh hoặc kết hợp với sự hoạt động mạnh của rìa lưỡi áp cao cận nhiệt Thái Bình Dương. Đặc biệt, dãy Trường Sơn có vai trò như một bức tường chắn, chặn các dòng mực thấp, khiến cho mưa ở Trung Bộ thường có cường độ lớn và gây lũ lụt trên phạm vi rộng [4-8]. Ở Nam Bộ, mưa chủ yếu gây ra bởi gió mùa tây nam và mưa thường tăng khi có sự hoạt động mạnh của gió mùa tây nam [9-12]. Các nghiên cứu cho thấy trong thời kì hoạt động của gió mùa tây nam, lượng mưa có mối liên hệ khá rõ ràng với chỉ số dao động nam [12].

Các nghiên cứu gần đây cho thấy mưa lớn diện rộng ở Nam Bộ thường liên quan đến sự phát triển của các dao động nội mùa $[10,13,14]$ chỉ ra rằng $\mathrm{MJO}$, sóng Kelvin, sóng Rossby xích đạo và sự tương tác giữa các sóng này có tác động lớn tới sự biến đổi của trường mưa tại Nam Bộ. Trong khi MJO có ảnh hưởng lớn nhất cả về lượng mưa và diện mưa, sóng Rossby xích đạo có tác động nhỏ hơn và có ảnh hưởng mạnh tại khu vực phía bắc của Nam Bộ. Ảnh hưởng của sóng Kelvin xếp thứ ba và chỉ rõ ràng ở khu vực phía nam của $12^{\circ} \mathrm{N}$. Các tác giả chỉ ra rằng mưa lớn ở Nam Bộ có xu hướng tăng trong các pha ẩm của $\mathrm{MJO}$ và các sóng xích đạo kết hợp đối lưu. Trong khi MJO tác động tới độ dầy của dòng gió tây ẩm và 
độ đứt gió, sóng Rossby xích đạo lại tác động tới hội tụ ẩm ở các mực thấp tầng đối lưu, dẫn đến sự phát triển của đối lưu sâu gây mưa lớn. Tuy nhiên, sự thay đổi của profile gió và độ ẩm trong việc gây ra mưa lớn tại Nam Bộ lại không thật rõ trong các pha ẩm của sóng Kelvin xích đạo.

Thống kê trong 29 năm (1981-2009), nghiên cứu [1] cho thấy mưa lớn ở Nam Bộ có liên quan chặt chẽ đến sự phát triển của dao động nội mùa. Mưa lớn ở khu vực khí hậu này thường xuất hiện vào tháng Tám và tháng Mười, trùng với hai cực đại của dao động nội mùa trong giai đoạn này. Nghiên cứu cũng cho thấy, trong pha hoạt động của dao động nội mùa, các sóng dạng nhiê̂u động nhiệt đới từ Tây Bắc Thái Bình Dương phát triển mạnh về phía tây bắc, tới bán đảo Đông Dương, tạo nên khu vực đối lưu mạnh di chuyển sang phía tây, là nguyên nhân chính dẫn đến sự xuất hiện mưa lớn. Nghiên cứu cũng nhấn mạnh vai trò của hệ thống sóng ngoại nhiệt đới, làm tăng cường hoàn lưu của sóng dạng nhiễu động nhiệt đới gây mưa lớn ở Nam Bộ.

Phú Quốc nằm ở phía tây nam của vùng Nam Bộ, là cửa ngõ đón gió mùa mùa hè. Từ ngày 1/8/2019 đến 5/8/2019, tại Nam Bộ và đặc biệt là Phú Quốc xuất hiện đợt mưa lớn kỉ lục với tổng lượng mưa đạt trên $1000 \mathrm{~mm}$, đáng kể nhất là ngày $2 / 8$ và $5 / 8$ lượng mưa tại Phú Quốc đạt lần lượt $168 \mathrm{~mm}$ và $265 \mathrm{~mm}$. Đây là đợt mưa lớn dị thường, đã gây ra rất nhiều thiệt hại về kinh tế xã hội cho khu vực này. Mặc dù là đợt mưa lớn gây hậu quả nghiêm trọng, khả năng dự báo của mô hình số trong đợt mưa lớn này còn rất hạn chế. Nghiên cứu hướng đến phân tích cơ chế gây mưa lớn này, nhằm tăng cường sự hiểu biết về các nguyên nhân gây mưa lớn ở Phú Quốc.

\section{Số liệu và phương pháp nghiên cứu}

\subsection{Số liệu thu thập}

Số liệu mưa quan trắc tại 10 trạm: Phú Quốc, Bạc Liêu, Cần Thơ, Côn Đảo, Đồng Phú, Rạch Giá, Vị Thanh, Tà Lài từ 1/7/2019 đến 15/8/2019 được cung cấp bởi Tổng cục Khí tượng Thủy văn dùng để để xác định những ngày mưa lớn diện rộng ở Nam Bộ và Phú Quốc. Số liệu mưa vệ tinh PERSIANN [15] được sử dụng để thể hiện phân bố mưa trên khu vực nghiên cứu, đây là bộ số liệu mưa được ước lượng từ vệ tinh địa tĩnh sử dụng mạng thần kinh nhân tạo và là bộ số liệu mưa được sử dụng rất phổ biến cho nghiên cứu mưa vùng nhiệt đới ở thời điểm hiện tại. Bộ số liệu được cho trên độ phân giải $0.25^{\circ} \times 0.25^{\circ}$ kinh vĩ và được phát triển bởi đại học California.

Để nghiên cứu sự phát triển của hoàn lưu quy mô lớn, số liệu FNL [16-17] được cung cấp bởi NOAA được sử dụng. Bộ số liệu này được đồng hóa bởi mô hình toàn cầu (GFS) và được cho trên độ phân giải $1^{\circ} \times 1^{\circ}$ kinh vĩ. Số liệu ngày được lấy trung bình từ 4 obs phân tích: 0000, 0006, 0012, 0018. Đồng thời, để biểu diễn sự phát triển của đối lưu, số liệu phát xạ sóng dài (OLR) với độ phân giải $2.5^{\circ} \times 2.5^{\circ}$ kinh vĩ được sử dụng [18]. Các nghiên cứu trước đây đã cho thấy số liệu OLR là một chỉ số rất tốt để chỉ thị cho sự phát triển của đối lưu sâu vùng nhiệt đới.

\subsection{Phương pháp nghiên cưu}

Để phân tích sự phát triển của gió mùa mùa hè trên khu vực Việt Nam, chỉ số gió mùa mùa hè VSMI $[9,19]$ được sử dụng. Chỉ số gió mùa được tính toán dựa trên trung bình gió vĩ hướng trong khu vực $5^{\circ} \mathrm{N}-15^{\circ} \mathrm{N} ; 100^{\circ} \mathrm{E}-110^{\circ} \mathrm{E}$ với công thức VSMI $=U 850 \mathrm{hPa}\left(5^{\circ} \mathrm{N}-\right.$ $\left.15^{\circ} \mathrm{N} ; 100^{\circ} \mathrm{E}-110^{\circ} \mathrm{E}\right)$. Kết quả nghiên cứu dựa trên số liệu tái phân tích trong vòng 30 năm của các tác giả này đã cho thấy VSMI phản ánh rất tốt sự phát triển của hoàn lưu quy mô lớn của gió mùa mùa hè, đồng thời cho mối liên hệ chặt chẽ với sự thay đổi lượng mưa ở Việt Nam.

Nghiên cứu sử dụng các chỉ số dao động nội mùa $\mathrm{PC} 1, \mathrm{PC} 2$ của $\mathrm{MJO}$ và $\mathrm{BSISO}$ [20], các chỉ số này được xây dựng dựa trên các giá trị của thành phần chính khi áp dụng phương 
pháp hàm trực giao mở rộng (Extended EOF) [21] lên giá trị dị thường của OLR trong giai đoạn 1979-2019. Để xây dựng chỉ số dao động nội mùa cho thời gian thực (real-time), giá trị dị thường của OLR được chiếu lên các EOF này.

\section{Kết quả và thảo luận}

\subsection{Các đặc trung mưa và hoàn lưu quy mô lớn liên quan}

Từ $1 / 7$ đến $15 / 8$, ở khu vực Nam Bộ xuất hiện 3 đợt mưa chính. Đợt 1 từ $1 / 7$ đến $7 / 7 / 2019$, đợt 2 từ $16 / 7$ đến 20/7/2019 và đợt 3 từ $1 / 8$ đến $5 / 8 / 2019$ (Hình 1 ). Trong đó, đợt mưa thứ 3 có cường độ lớn nhất, với lượng mưa phổ biến từ 30 đến $50 \mathrm{~mm} / \mathrm{ngày,} \mathrm{đặc} \mathrm{biệt} \mathrm{ở}$ Phú Quốc, lượng mưa đạt được từ 100 đến trên $250 \mathrm{~mm} / \mathrm{ngày}$. Mặc dù lượng mưa phân bố không đồng đều giữa các trạm, tuy nhiên có thể thấy một xu thế chung, lượng mưa tại các trạm tăng dần trong các giai đoạn tăng của chỉ số gió mùa VSMI. Giá trị của VSMI càng lớn, lượng mưa quan trắc được càng cao, điều này cho thấy mối liên hệ chặt chẽ giữa chỉ số gió mùa mùa hè và mưa ở Nam Bộ và đặc biệt là Phú Quốc. Tại một số trạm, mưa có xu thế xuất hiện trễ hơn so với cực đại VSMI khoảng 1-2 ngày. Tuy nhiên, có thể khẳng định, sự xuất hiện của mưa lớn tại giai đoạn này liên quan đến sự mạnh lên của hoàn lưu gió mùa mùa hè ở khu vực gió mùa Nam Á.

Sự phát triển của mưa vệ tinh và hoàn lưu quy mô lớn trong giai đoạn mưa từ 29/7 đến $5 / 8 / 2019$ được thể hiện trong Hình 2 . Tương đồng với kết quả thể hiện từ mưa quan trắc, mưa lớn chủ yếu tập trung tại Phú Quốc và một số trạm ở phía nam của Nam Bộ. Mưa bắt đầu xuất hiện từ 29/7 dưới dạng một dải mưa hẹp từ Malaysia tới phía nam Biển Đông và liên tục duy trì trong các ngày còn lại. Lượng mưa tăng dần trong các ngày $1 / 8-5 / 8$ và có xu hướng di chuyển sang phía đông. Có thể thấy, sự tăng cường của mưa tại Nam Bộ trong giai đoạn này xuất hiện đồng thời với sự tăng cường của mưa tại khu vực gió mùa mùa hè Ân Độ và gió mùa mùa hè Tây Bắc Thái Bình Dương. Do đó, nguyên nhân gây mưa ở Phú Quốc trong giai đoạn này không chỉ đơn thuần gây ra bởi các quá trình quy mô địa phương, mà liên quan đến sự phát triển của toàn bộ hệ thống gió mùa mùa hè Châu Á.

Để khẳng định cho nhận định này, sự phát triển của hoàn lưu quy mô lớn trong giai đoạn mưa lớn này được thể hiện trong Hình 2 . Trong suốt giai đoạn này, gió tây nam có cường độ mạnh đã phát triển rất nhanh, tạo thành một dải lớn từ biển Ẩ rập, qua Ấn Độ, bán đảo Đông Dương và mở rộng tới Tây Thái Bình Dương. Các dòng vượt xích đạo từ nam bán cầu lên bắc bán cầu, đặc biệt từ Châu Úc, qua Maritime Continent tới bán đảo Đông Dương cũng có sự tăng cường rõ rệt. Có thể thấy tại khu vực gió mùa mùa hè Ân Độ, sự tăng cường của gió mùa tây nam đã vận chuyển một lượng ẩm lớn từ vịnh Bengal, gây mưa lớn tại khu vực Bangladesh và phía tây của Myanmar. Dãy núi Dawna chạy dọc đất nước Myanmar đóng vai trò như một bức tường chắn, chặn các dòng gió tây nam mực thấp, gây nên mưa lớn ở sườn phía tây của dãy núi này. Tại khu vực gió mùa Tây Bắc Thái Bình Dương, mưa tập trung chủ yếu tại các xoáy thuận nhiệt đới ở phía đông và phía bắc Philippines. Mưa lớn ở Phú Quốc nằm ở khu vực chuyển giao của hai hệ thống này.

Để tìm hiểu nguyên nhân của sự tăng cường của gió mùa tây nam trong giai đoạn này, giá trị áp suất mực biển được vẽ trong Hình 3. Có thể thấy, trong ngày 28/8/2019, gió tây nam tương đối yếu và chỉ giới hạn ở khu vực Ấn Độ Dương và phía nam Biển Đông, do sự phát triển yếu của vùng áp thấp tại khu vực phía bắc Ấn Độ. Tuy nhiên, sang ngày 30/8/2019, vùng áp thấp ở Ân Độ khơi sâu rất nhanh làm tăng cường gió tây nam ở phía nam khu vực áp thấp này. Đồng thời với đó là sự mở rộng của khu vực áp thấp tại Tây Thái Bình Dương, bao phủ một khu vực rộng lớn từ Biển Đông tới gần trung tâm Thái Bình Dương. Một mặt, sự mở rộng của khu vực áp thấp tại Tây Thái Bình Dương làm tăng cường gió tây tại Biển Đông, mặt khác, sự giảm áp này tạo điều kiện thuận lợi để hình thành nên các áp thấp và bão nhiệt đới. Với nhiệt độ mặt nước biển được duy trì cao, kết hợp với độ đứt gió lớn trong nửa đầu tháng Tám (Hình 4), trong giai đoạn này đối lưu sâu đã liên tục phát triển mạnh. Các 
ngày tiếp theo, vùng áp thấp tại Tây Thái Bình Dương tiếp tục khơi sâu, kết hợp với vùng áp thấp tại Ấn Độ, hình thành nên dải gió tây nhiệt đới mạnh từ Ấn Độ Dương tới Tây Thái Bình Dương. Với nguồn ẩm dồi dào được cung cấp tại các khu vực biển có nhiệt độ bề mặt cao này, sự hội tụ của đới gió tây nam dễ dàng tạo nên các tổ chức đối lưu sâu và gây mưa lớn. Khu vực Phú Quốc lúc này nằm ở khu vực hội tụ của 3 đới gió chính: gió tây từ vịnh Bengal, dòng gió vượt xích đạo từ Châu Úc lên bắc bán cầu và dòng gió tây bắc ở Biển Đông. Sự hội tụ mạnh của các đới gió đã dẫn đến sự xuất hiện của mưa lớn ở khu vực trong giai đoạn này. Do giới hạn của khu vực hội tụ chỉ ở Phú Quốc và một số khu vực phía nam của Nam Bộ, điều này cũng giải thích tại sao mưa lớn chỉ tập trung ở khu vực này mà không mở rộng lên toàn bộ Nam Bộ. Khu vực áp thấp tại Tây Thái Bình Dương tiếp tục khơi sâu và duy trì đến ngày 15/8/2019. Các ngày sau đó, gió tây nam suy yếu và chỉ được giới hạn thành một dải hẹp từ Bengal tới phía nam Trung Quốc. Sự suy yếu của gió mùa tây nam cũng đồng thời với sự giảm của cường độ mưa tại Phú Quốc.
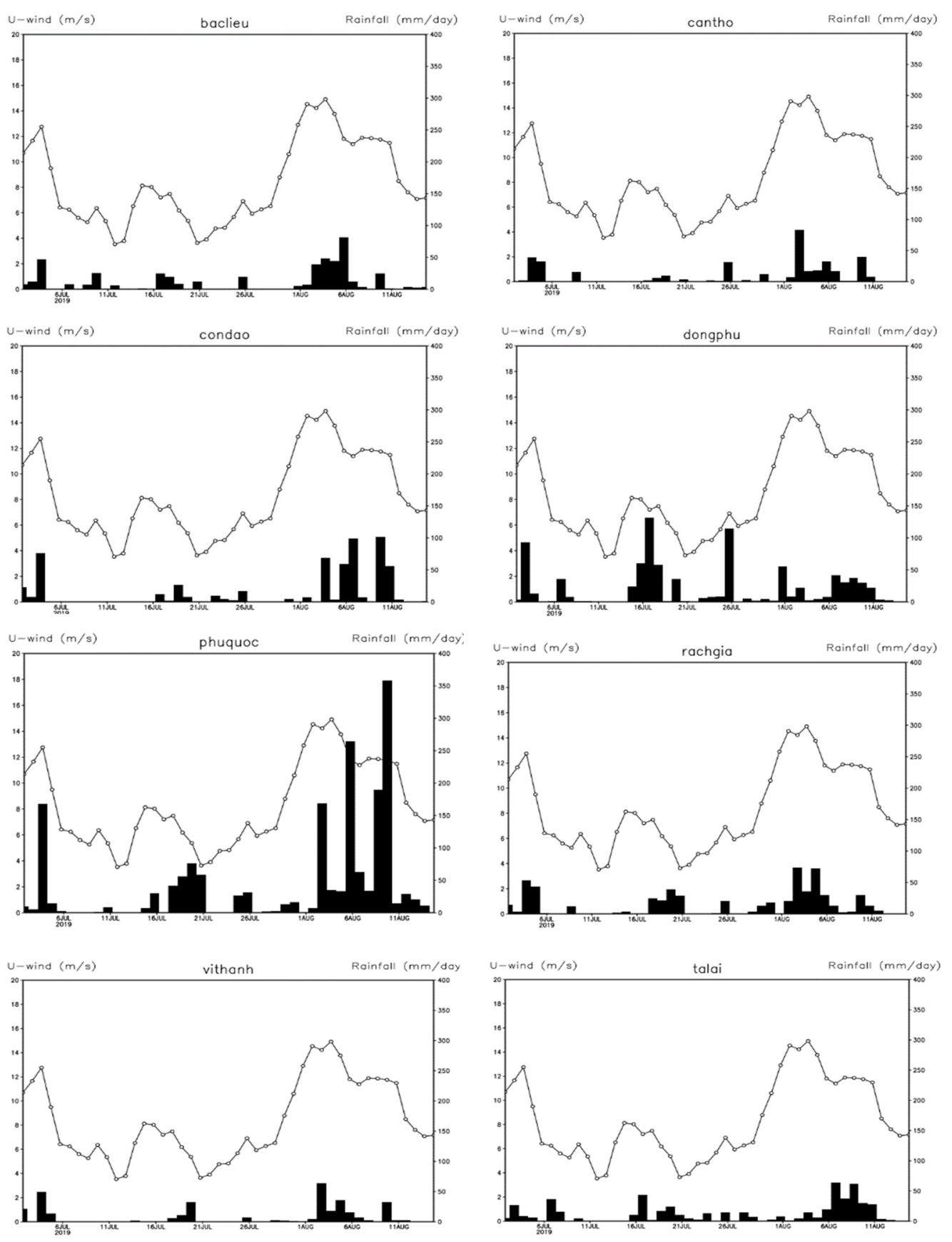

Hình 1. Giá trị mưa quan trắc (cột màu đen) và chỉ số gió mùa VSMI (đường liền) từ 1/7-15/8/2019. 

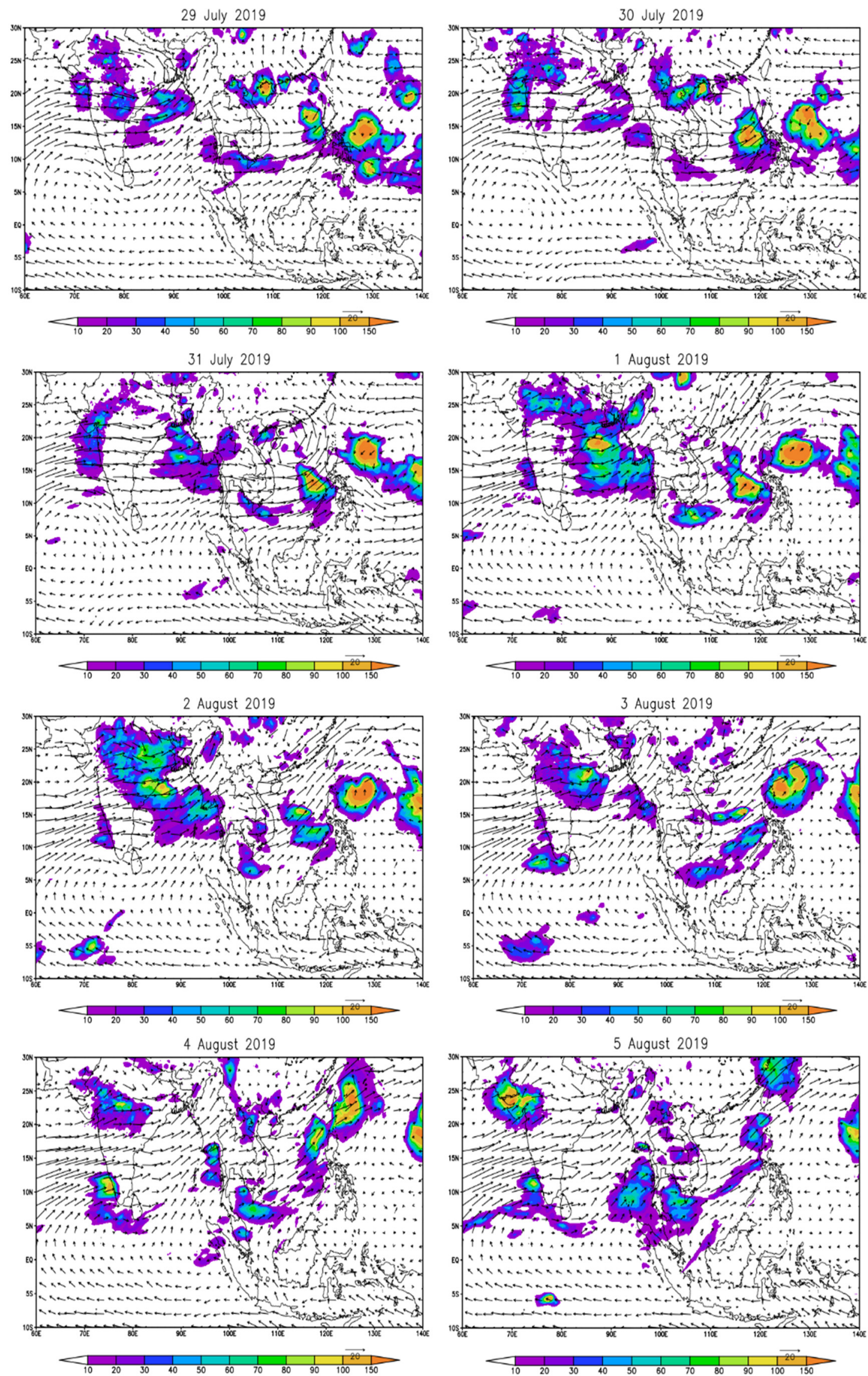

Hình 2. Gió mực 850hPa (vector) và mưa vệ tinh PERSIANN (mm/ngày) từ 29/7 đến 5/8/2019. 
28 August 2019

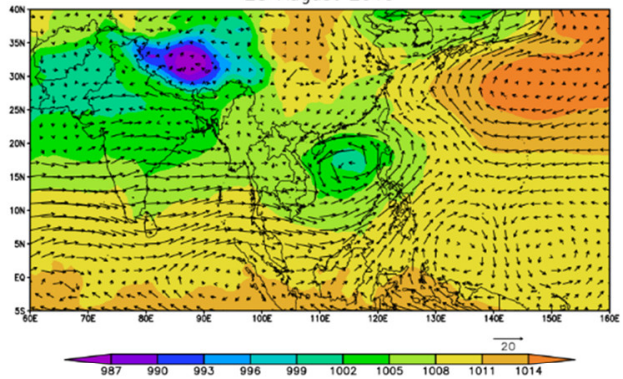

1 August 2019

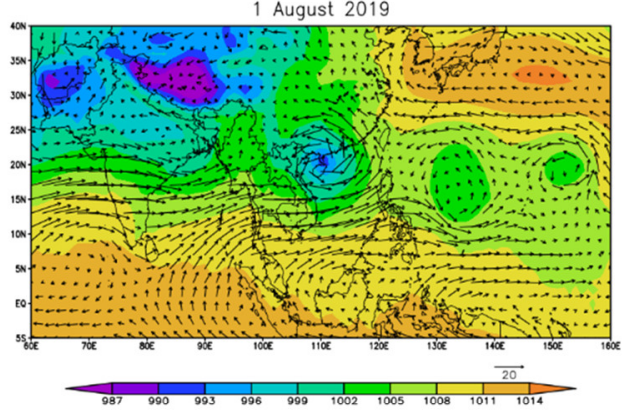

5 August 2019
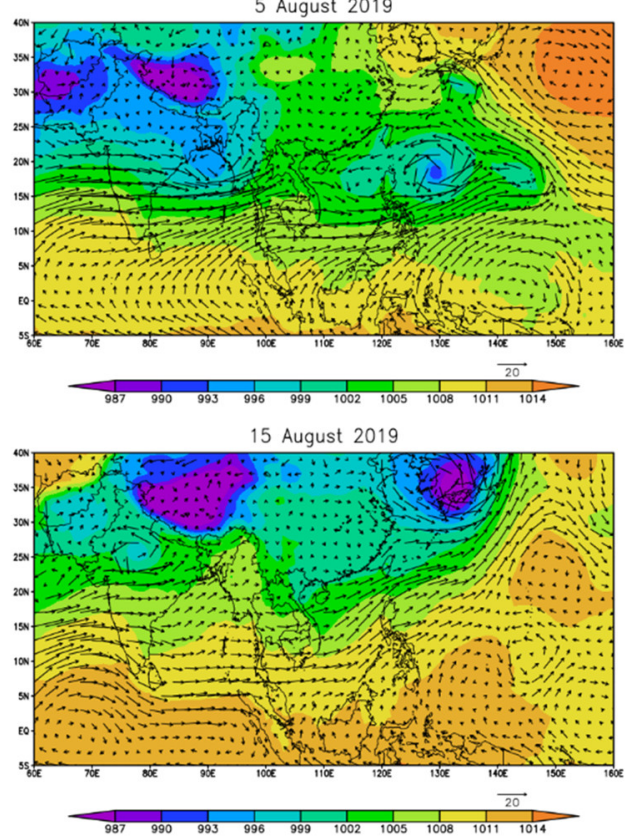

30 July 2019

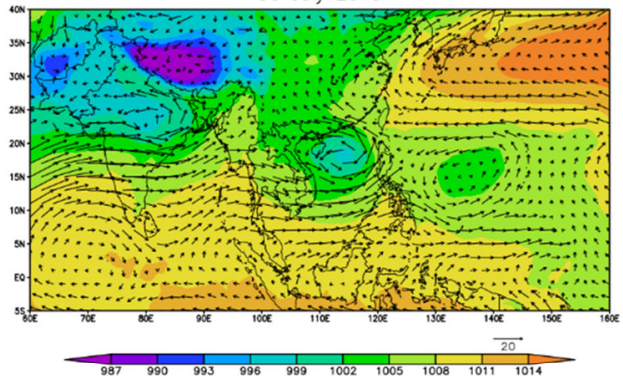

3 August 2019

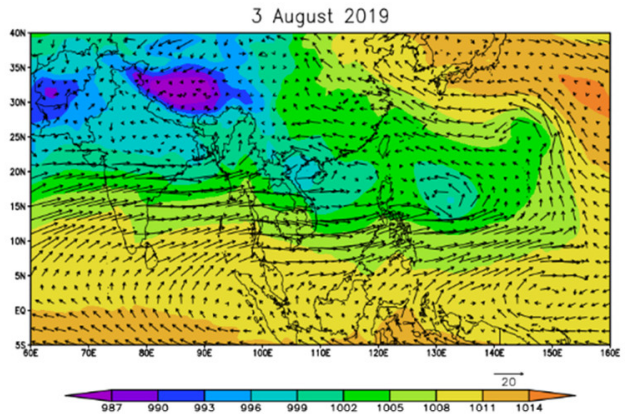

7 August 2019
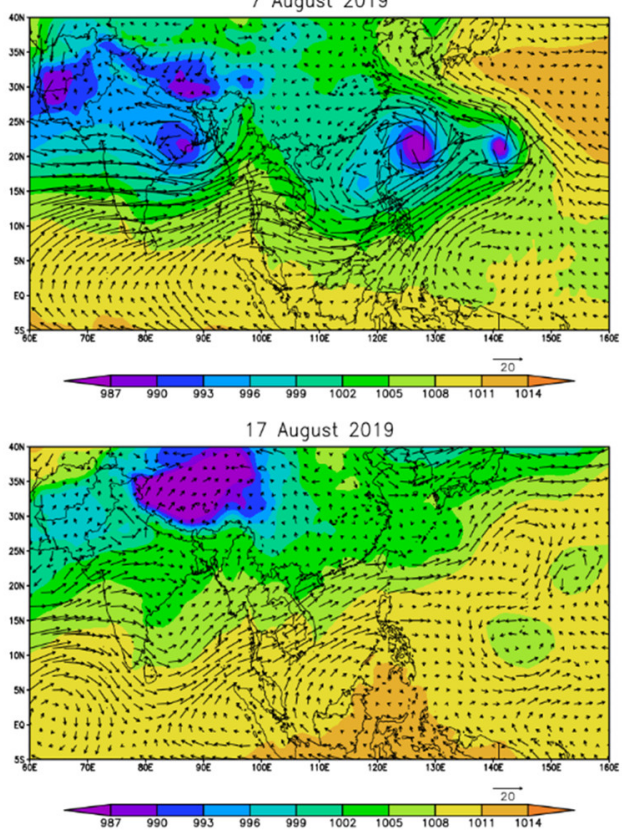

Hình 3. Gió mực $850 \mathrm{hPa}$ (vector) và áp suất mực biển (hPa) từ ngày $29 / 7$ đến 5/8/2019.
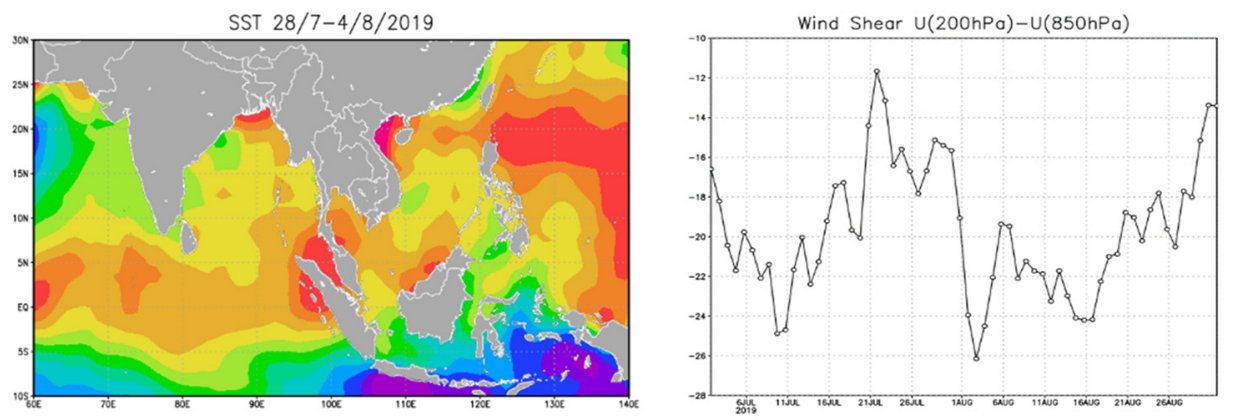

Hình 4. Nhiệt độ mặt biển từ $28 / 7$ đến $4 / 8 / 2019\left({ }^{\circ} \mathrm{C}\right.$, hình phải) và dộ đứt gió $(\mathrm{m} / \mathrm{s}$, hình trái). 


\subsection{Vai trò của dao động nội mùa}

Sự mở rộng và khơi sâu của khu vực áp thấp tại Ấn Độ và Tây Thái Bình Dương từ 29/7 đến $15 / 8$ cho thấy sự hoạt động của dao động nội mùa của gió mùa mùa hè Châu Á với chu kì khoảng hơn 30 ngày. Sự hoạt động của dao động nội mùa này được nhận thấy rõ nét hơn trong Hình 5. Có thể thấy, trong giai đoạn mưa lớn ở Phú Quốc, có một sự di chuyển rất ổn định từ phía tây sang phía đông của hệ thống đối lưu sâu. Tốc độ di chuyển sang phía đông của hệ thống đối lưu này vào khoảng xấp xỉ $6 \mathrm{~m} / \mathrm{s}$, tương đương với tốc độ di chuyển thường thấy của dao động Madden Julian (MJO) và dao động mùa hè bắc bán cầu (BSISO). Đối lưu sâu xuất phát từ khoảng $60^{\circ} \mathrm{E}$, phát triển rất mạnh ở khu vực Ấn Độ Dương. Khi đến Maritime Continent, đối lưu suy yếu do địa hình nhưng vẫn tiếp tục di chuyển sang phía đông với tốc độ không đổi. Sau khi vượt qua Maritime Continent tới khu vực Tây Thái Bình Dương, đối lưu có dấu hiệu mạnh trở lại và tiếp tục di chuyển tiếp sang phía đông. Do đó, có thể khẳng định, mưa lớn ở Phú Quốc trong giai đoạn này có liên quan đến sự hoạt động của dao động nội mùa của gió mùa mùa hè Châu Á với chu kì ước lượng khoảng hơn 30 ngày. Điều này cũng giải thích sự khơi sâu đồng thời của hệ thống áp thấp tại Ấn Độ và Tây Thái Bình Dương từ ngày 29/7-15/8/2019.

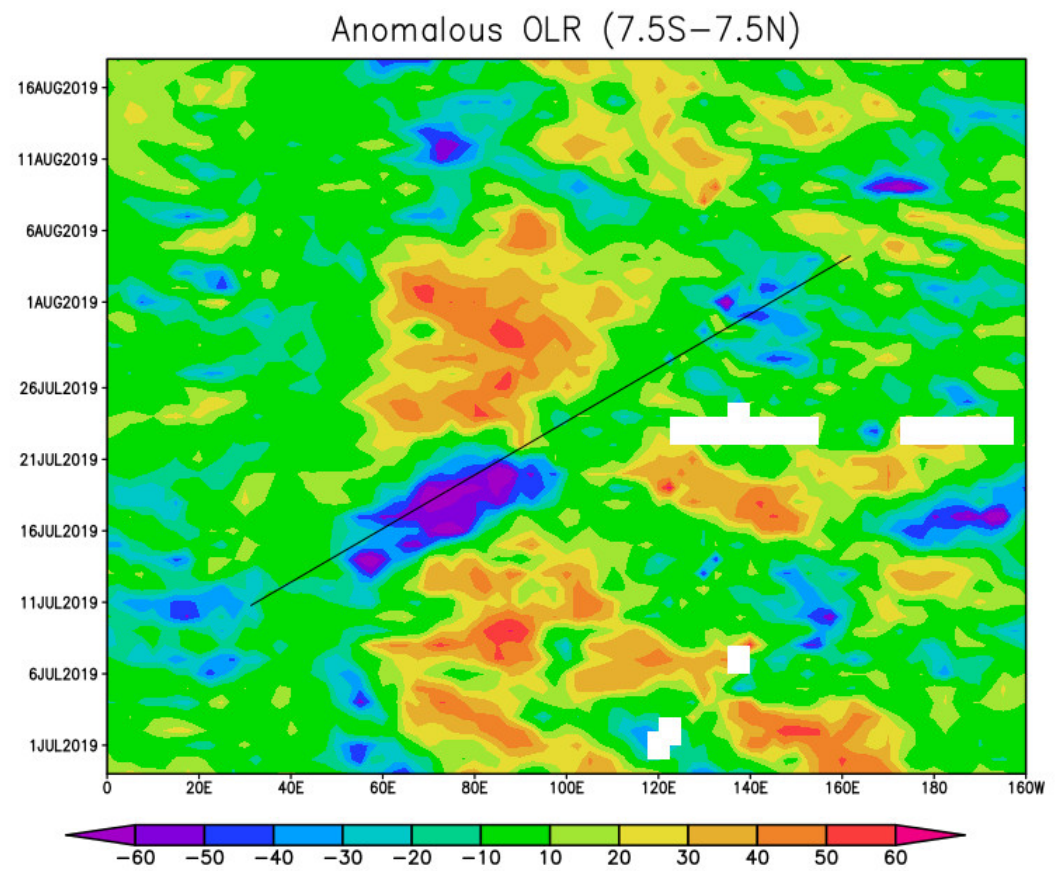

Hình 5. Biểu đồ dị thường OLR từ ngày $1 / 7$ đến 16/8.

Để nhận diện dao động nội mùa trong giai đoạn này, chỉ số dao động nội mùa [20] được biểu diễn trong Hình 6. Có thể thấy, giá trị $\mathrm{PC} 1$ và $\mathrm{PC} 2$ ứng với dao động $\mathrm{MJO}$ trong giai đoạn này rất yếu (nhỏ hơn 1 độ lệch chuẩn), do đó, sự di chuyển sang phía đông của đối lưu sâu trong giai đoạn này không liên quan đến sự phát triển của MJO. Tuy nhiên, có thể thấy từ 30/7 đến 15/8/2019, $\mathrm{PC} 1$ và $\mathrm{PC} 2$ của $\mathrm{BSISO}$ đạt giá trị rất lớn, xấp xỉ 2 độ lệch chuẩn, cho thấy sự hoạt động mạnh của BSISO trong giai đoạn này. Đặc biệt từ khoảng $1 / 8$ đến 16/8, các giá trị $\mathrm{PC} 1$ và $\mathrm{PC} 2$ đều đạt cực trị, trùng với giai đoạn xuất hiện mưa lớn tại Phú Quốc. Do đó, có thể khẳng định, mưa lớn tại Phú Quốc trong giai đoạn này gây ra bởi dao động BSISO của gió mùa mùa hè Châu Á, với chu kì khoảng hơn 30 ngày.

Năng lượng đối lưu tiềm tàng (CAPE) là tích phân của năng lượng của một phần tử trong quá trình di chuyển thẳng đứng khi đối lưu được giải phóng. CAPE càng lớn cho thấy năng lượng tiềm tàng càng lớn, có thể gây lên dòng thăng rất mạnh, là môi trường thuận lợi để xuất hiện các hiện tượng cực đoan như gió giật, mưa lớn, mưa đá... Trong nghiên cứu này, giá trị CAPE bề mặt được phân tích để nhận định cơ chế gây mưa lớn tại Phú Quốc (Hình 7). 
Có thể thấy trong suốt giai đoạn mưa lớn, khu vực Phú Quốc nằm trong vùng có giá trị CAPE lớn $(>1200 \mathrm{~J} / \mathrm{kg})$. Giá trị CAPE lớn này là một phần của dải CAPE lớn từ Ấn Độ Dương tới Tây Thái Bình Dương. Giá trị CAPE lớn này giải thích cho sự hình thành của các vùng đối lưu lớn, gây mưa lớn tại Phú Quốc. Sự hoạt động của BSISO đã tạo nên các khu vực hội tụ ẩm mực thấp lớn, cung cấp nguồn ẩm dồi dào trong lớp biên, khiến khí quyển ở trong trạng thái bất ổn định có điều kiện lớn. Tương tự như các phân tích trước, giá trị CAPE lớn chỉ được quan sát thấy ở Phú Quốc và khu vực phía nam Nam Bộ, do đó, mưa lớn chỉ phổ biến ở Phú Quốc mà không phát triển lên các khu vực khác của Nam Bộ và Tây Nguyên.

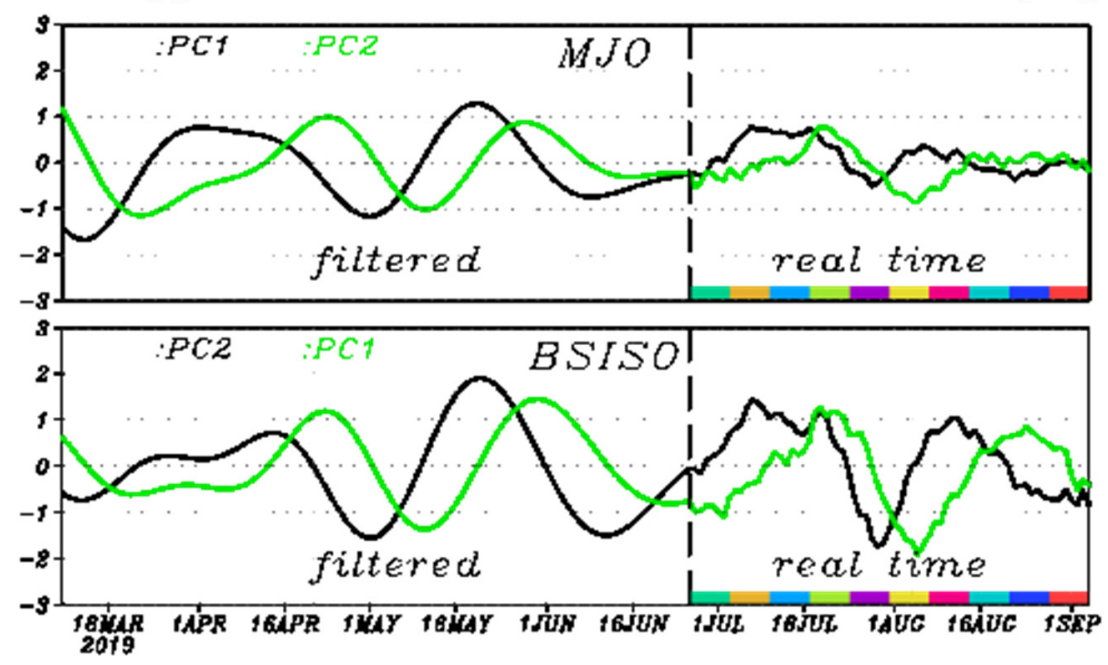

Hình 6. Các chỉ số MJO và BSISO trong cùng giai đoạn [22].
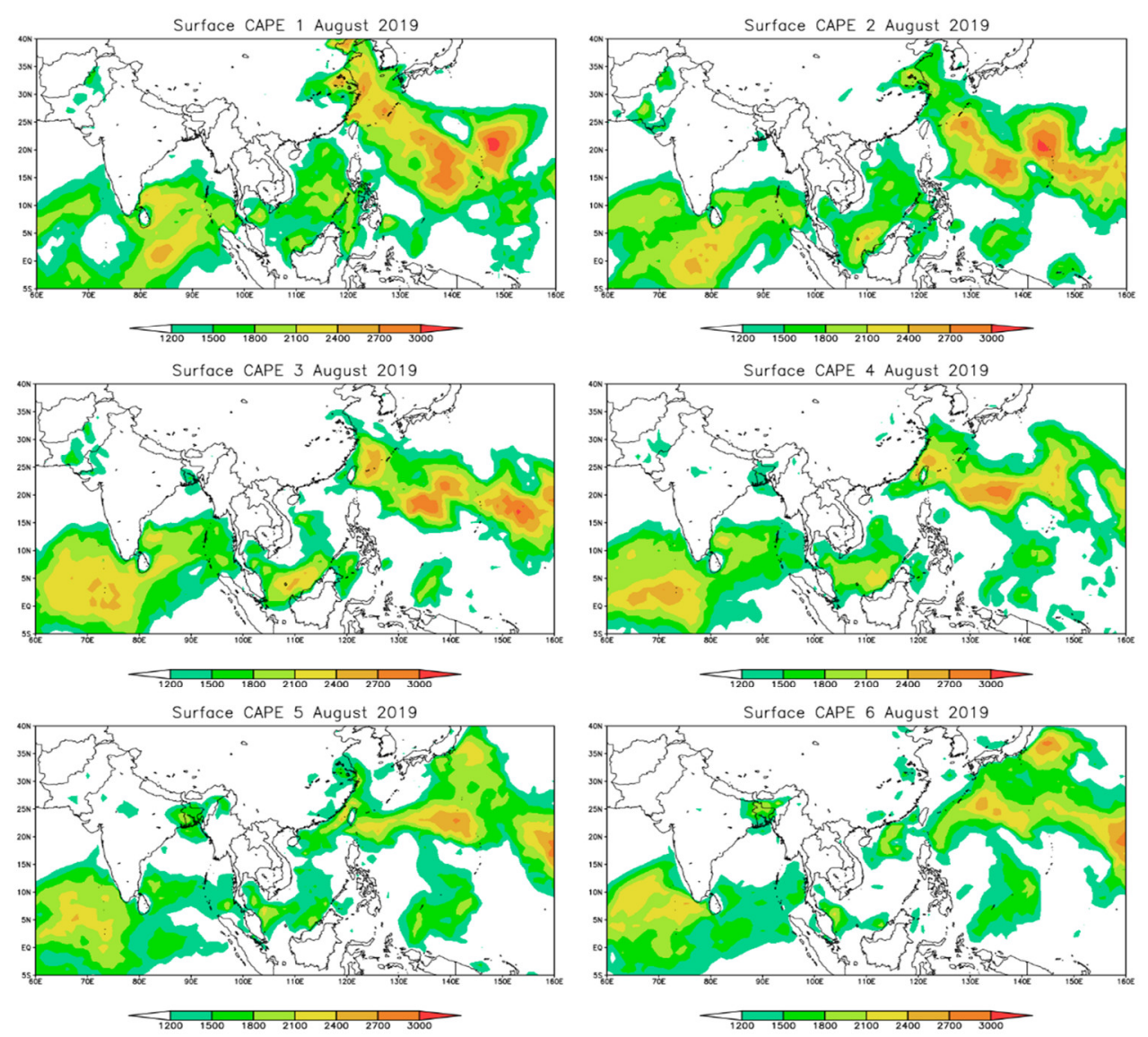

Hình 7. Giá trị CAPE bề mặt từ ngày $1 / 8$ đến 6/8/2019. 


\section{Kết luận}

Nghiên cứu tìm hiểu cơ chế gây mưa lớn tại Nam Bộ từ ngày $1 / 8$ đến ngày $5 / 8 / 2019$, sử dụng số liệu mưa quan trắc, mưa vệ tinh và số liệu FNL, một số kết quả chính thu được như sau: (1) Mưa lớn xuất hiện đồng thời với sự tăng cường của gió mùa mùa hè tại khu vực Việt Nam, được biểu diễn thông qua của chỉ số VSMI; (2) Sự tăng cường của gió mùa mùa hè trong giai đoạn này liên quan chặt chẽ đến sự phát triển của dao động nội mùa của gió mùa mùa hè Châu Á (BSISO); (3) Sự phát triển của dao động nội mùa khiến cho khí áp tại Ấn Độ và Tây Thái Bình Dương giảm mạnh, tăng cường gió tây nam và dòng vượt xích đạo, hội tụ và gây mưa lớn tại Nam Bộ.

Đóng góp của tác giả: Xây dựng nghiên cứu: N.D.M.; Lựa chọn phương pháp nghiên cứu: N.D.M., H.T.H., V.Q.T.; Xử lý số liệu: H.T.H., V.Q.T.; Viết bản thảo bài báo: N.D.M., V.Q.T., H.T.H.; Chỉnh sửa bài báo: N.D.M.

Lời cảm ơn: Nhóm nghiên cứu xin chân thành cảm ơn sự hỗ trợ của đề tài khoa học công nghệ cấp Bộ TNMT "Nghiên cứu hoạt động của tín phong (Trade wind) và ảnh hưởng đến thời tiết, khí hậu ở Việt Nam”, mã số: TNMT.2021.562.05 trong việc thực hiện và công bố nghiên cứu này.

Lời cam đoan: Tập thể tác giả cam đoan bài báo này là công trình nghiên cứu của tập thể tác giả, chưa được công bố ở đâu, không được sao chép từ những nghiên cứu trước đây; không có sự tranh chấp lợi ích trong nhóm tác giả.

\section{Tài liệu tham khảo}

1. Tuan, B.M. Extratropical Forcing of Submonthly Variations of Rainfall in Vietnam. J. Clim. 2019, 32, 2329-2348.

2. Chen, T.C.; Yen, M.C.; Tsay, J.D.; Thanh, N.T.T.; Alpert, J. Synoptic development of the Hanoi heavy rainfall event of 30-31 October 2008: Multiple-scale processes. Wea. Forecasting 2012, 27, 1155-1177.

3. Dư, C.Đ.; Chính, P.Đ. Mưa gây lũ quét ở vùng núi Bắc Bộ. Tạp chí Khí tượng Thủy văn 2006, 542, 15-26.

4. Wu, P.; Fukutomi, Y.; Matsumoto, J. The impact of intraseasonal oscillations in the tropical atmosphere on the formation of extreme central Vietnam precipitation. Sci. Online Lett. Atmos. 2012, 8, 57-60.

5. Quang, L.Đ. Đặc điểm mưa lớn ở miền trung Việt Nam. Tạp chí Khí tương Thủy văn 2005, 536, 1-9.

6. Yokoi, S.; Matsumoto, J. Collaborative effects of cold surge and tropical depression type disturbance on heavy rainfall in central Vietnam. Mon. Wea. Rev. 2008, 136, 3275-3287.

7. Nguyen-Le, D.; Matsumoto, J. Delayed withdrawal of the autumn rainy season over central Vietnam in recent decades. Int. J. Climatol. 2016, 36, 3002-3019.

8. Vân, N.K.; Thủy, Đ.L. Nguyên nhân và quy luật của thời tiết mưa lớn, mưa lớn trái mùa vùng Bắc Trung Bộ (giai đoạn 1987-2006). Tạp chí các Khoa học về trái đất 2009, 31, 279-286.

9. Nguyen, D.M.; Nguyen, V.T. Definition of new summer monsoon index for Vietnam region. VN J. Sci. Technol. Eng. 2018, 60, 90-96.

10. Tuân, B.M.; Trường, N.M.; Hằng, V.T.; Thanh, C. Sự dịch chuyển lên phía bắc của dao động nội mùa và cơ chế dao động nội mùa của lượng mưa tại Bắc Bộ và Nam Bộ. Tạp chí Khoa học ĐHQGHN: Các Khoa học Trái đất và Môi truờng 2016, 32(3S), 243-249. 
11. Tuân, B.M.; Trường, N.M. Xây dựng chỉ số xác định ngày bùng nổ gió mùa mùa hè ở Nam Bộ sử dụng mô hình số với số liệu tái phân tích. Tạp chí khoa học Đại học Quốc gia Hà Nội: Khoa học Tự nhiên và Công nghệ 2013, 29, 187-195.

12. Thông, M.T.; Thủy, H.L.T. Mối quan hệ giữa lượng mưa với các chỉ số ENSO trên các vùng thuộc lãnh thổ Việt Nam. Tạp chí Khí tuợng Thủy văn 2007, 553, 80668744.

13. Van der Linden, R.; Fink, A.H.; Pinto, J.G.; Phan-Van, T.; Kiladis, G.N. Modulation of Daily Rainfall in Southern Vietnam by the Madden-Julian Oscillation and Convectively Coupled Equatorial Waves. J. Clim. 2016, 29, 5801-5820. https://doi.org/10.1175/jcli-d-15-0911.1.

14. Truong, N.M.; Tuan, B.M. Structures and Mechanisms of 20-60-Day Intraseasonal Oscillation of the Observed Rainfall in Vietnam. J. Clim. 2019, 32, 5191-5212.

15. Nguyen, P.; Shearer, E.J.; Tran, H.; Ombadi, M.; Hayatbini, N.; Palacios, T.; Huynh, P.; Braithwaite, D.; Updegraff, G.; Hsu, K.; Kuligowski, B.; Logan, W.S.; Sorooshian, S. The CHRS Data Portal, an easily accessible public repository for PERSIANN global satellite precipitation data. Sci Data. 2019, 6, 180296. https://doi.org/10.1038/sdata.2018.296.

16. NCEP GDAS/FNL 0.25 Degree Global Tropospheric Analyses and Forecast Grids. https://rda.ucar.edu/datasets/ds083.3/.

17. Peng, G. What's the difference between FNL and GFS?. 2014. https://rda.ucar.edu/datasets/ds083.2/docs/FNLvGFS.pdf

18. Liebmann, B.; Catherine, A.S. Description of a complete (interpolated) outgoing longwave radiation dataset. Bull. Am. Meteorol. Soc. 1996, 77, 1275-1277.

19. Mậu, N.Đ.; Thắng, N.V.; Khiêm, M.V.; Linh, L.N.; Hiệu, N.T. Nghiên cứu chỉ số gió mùa mùa hè cho khu vực Việt Nam. Tạp chí Khí tượng thủy văn 2016, 662, 3-9.

20. Kikuchi, K.; Wang, B.; Kajikawa, Y. Bimodal representation of the tropical intraseasonal oscillation. Clim. Dyn. 2012, 38, 1989-2000.

21. Hannachi, A. A Primer for EOF Analysis of Climate Data. 2004.

22. http://iprc.soest.hawaii.edu/users/kazuyosh/Bimodal_ISO.html.

\title{
Mechanism causing extreme heavy rainfall during 1-5 August 2009 at Phu Quoc island
}

\author{
Nguyen Dang Mau ${ }^{1 *}$, Hoang Thi Huyen ${ }^{1}$, Vu Quoc Tuan ${ }^{2}$ \\ ${ }^{1}$ Vietnam Institute of Meteorology, Hydrology and Climate Change; \\ mau.imhen@gmail.com; huyenht.imh@gmail.com \\ ${ }^{2}$ National Center for Hydro-Meteorological Forecasting; vuquoctuan5895@gmail.com
}

Abstract: In this study, the mechanism of heavy rainfall in PhuQuoc from 1/8-5/8/2019 is analysed based on the observation rainfall, satellite rainfall and FNL data. The results show that heavy rainfall in PhuQuoc is associated with the enhancement of westerly monsoon which can be defined by VSMI. This westerly enhancement is closely related to the activation of intraseasonal oscillation with the cycle of about 30 days over Indian Ocean and North Western Pacific. The results also show that the deeping of monsoon trough over the two regions lead to the strong moisture convergence over PhuQuoc and induce heavy rainfall in this island.

Keywords: Heavy rainfall; Intraseasonal oscillation; Large--scale circulation. 